\title{
PENGGUNAAN MODEL PEMBELAJARAN PROBLEM POSING UNTUK MENINGKATKAN HASIL BELAJAR SISWA PADA MATA PELAJARAN MEKANIKA TEKNIK DAN ELEMEN MESIN
}

\author{
Nur M. S. Mizwar ${ }^{1}$, Purnawan ${ }^{2}$, Asep H. Sasmita ${ }^{3}$ \\ Departemen Pendidikan Teknik Mesin \\ Universitas Pendidikan Indonesia \\ Jl. Dr. Setiabudhi No. 207 Bandung 40154 \\ mizwar.nms@gmail.com
}

\begin{abstract}
ABSTRAK
Penelitian ini bertujuan untuk meningkatkan hasil belajar siswa pada pembelajaran gaya dalam mata pelajaran Mekanika Teknik dan Elemen Mesin melalui penggunaan model pembelajaran Problem Posing. Penelitian ini dilatarbelakangi oleh rendahnya hasil belajar siswa pada pembelajaran gaya dalam mata pelajaran Mekanika Teknik dan Elemen Mesin. Beberapa informasi yang ditemukan yaitu proses pembelajaran menggunakan strategi pembelajaran ekspositori, siswa pasif dalam proses pembelajaran, dan siswa tidak termotivasi mencari informasi sendiri (eksplorasi). Jenis penelitian yang digunakan adalah penelitian tindakan kelas (PTK) yang terdiri dari tiga siklus. Masing-masing siklus terdiri dari satu pertemuan tatap muka yang dilakukan pada kelas X TM 3 SMK Negeri 2 Bandung sebanyak 32 siswa. Penelitian ini melibatkan dua orang pengamat pelaksanaan pembelajaran. Pada penelitian ini, proses pengumpulan data menggunakan teknik tes (tes bentuk pilihan ganda) dan observasi (observasi pelaksanaan pembelajaran). Hasil penelitian menunjukan adanya peningkatan hasil belajar, rata-rata $\mathrm{N}$-Gain pada siklus I sebesar 0,27 meningkat menjadi 0,35 pada siklus II, dan menjadi 0,45 pada siklus III. Persentase siswa yang mencapai KKM pada siklus I sebesar 31,3\% meningkat menjadi 68,8\% pada siklus II, dan menjadi $78,1 \%$ pada siklus III. Dapat disimpulkan bahwa penggunaan model pembelajaran Problem Posing dapat meningkatkan hasil belajar siswa pada pembelajaran gaya dalam mata pelajaran Mekanika Teknik dan Elemen Mesin.
\end{abstract}

Kata kunci: problem posing, mekanika teknik, elemen mesin, gaya.

\section{PENDAHULUAN}

Sekolah Menengah Kejuruan (SMK) merupakan satuan pendidikan yang secara khusus dipersiapkan untuk mencetak lulusan yang mampu bekerja secara efektif dan efisien serta mengembangkan keahlian dan keterampilannya. Sebagaimana tercantum pada Peraturan Menteri Pendidikan Nasional Republik Indonesia Nomor 22 Tahun 2006 tentang Standar Isi untuk Satuan Pendidikan Dasar dan Menengah bahwa agar dapat bekerja secara efektif dan efisien serta mengembangkan keahlian dan keterampilan, mereka harus memiliki stamina yang tinggi, menguasai bidang keahliannya dan dasar-dasar ilmu pengetahuan dan teknologi, memiliki etos kerja yang tinggi, dan mampu berkomunikasi sesuai dengan tuntutan pekerjaannya, serta memiliki kemampuan mengembangkan diri. Oleh karena itu, pada Kurikulum 2013 sebagai kurikulum yang diterapkan di berbagai lembaga pendidikan di

\footnotetext{
${ }^{1}$ Mahasiswa Departemen Pendidikan Teknik Mesin FPTK UPI

${ }^{2}$ Dosen Departemen Pendidikan Teknik Mesin FPTK UPI

${ }^{3}$ Dosen Departemen Pendidikan Teknik Mesin FPTK UPI
} 
Indonesia disematkan mata pelajaran Mekanika Teknik dan Elemen Mesin pada program keahlian Teknik Mesin (TM).

Mekanika Teknik dan Elemen Mesin merupakan mata pelajaran yang membahas konsep-konsep dasar yang dibutuhkan untuk perencanaan elemen mesin, seperti elemen mesin poros dan pasak, transmisi (pulley dan belt, rantai, kopling, dan roda gigi), dan elemen mesin yang disambungkan dengan keling, pasak, baut, dan las. Siswa dituntut untuk memahami materi pada mata pelajaran Mekanika Teknik dan Elemen Mesin agar siswa mampu menguasai bidang keahlian dan dasar-dasar ilmu pengetahuan dan teknologi (belajar).

Belajar merupakan suatu kegiatan yang dilakukan untuk menambah wawasan, ilmu, keterampilan, dan daya berpikir. Belajar merupakan aktivitas yang disengaja dan dilakukan oleh individu agar terjadi perubahan kemampuan diri. Dengan belajar anak yang tadinya tidak mampu melakukan sesuatu, menjadi mampu melakukan sesuatu, atau anak yang tadinya tidak terampil menjadi terampil (Ruhimat, 2013). Hasil belajar bisa diketahui melalui tes yang diselenggarakan, salah satunya ulangan harian.

Hasil belajar ulangan harian pada pembelajaran gaya dalam mata pelajaran Mekanika Teknik dan Elemen Mesin di kelas X TM 3 SMK Negeri 2 Bandung tahun pelajaran 2016/2017 masih terbiang rendah, yaitu persentase siswa yang belum mencapai KKM $(71,43 \%)$ lebih besar daripada persentase siswa yang mencapai KKM. Disamping itu, didapatkan beberapa informasi pada pembelajaran gaya yang berkaitan dengan faktor-faktor yang memengaruhi hasil belajar, antara lain: proses pembelajaran menggunakan strategi pembelajaran ekspositori; sarana dan prasarana yang tersedia di sekolah sudah lengkap; lingkungan sekolah nyaman dipakai untuk proses pembelajaran; faktor spiritual terpenuhi dengan diadakannya kegiatan keagamaan setiap hari; dan siswa pasif dalam proses pembelajaran dan tidak termotivasi dalam mencari informasi sendiri (eksplorasi).

Hasil belajar siswa disebabkan oleh faktor internal dan faktor ekternal. Faktor internal siswa, yaitu faktor fisiologis (struktur tubuh, cacat tubuh), faktor psikologis (inteligensi, bakat, prestasi, sikap, minat, kebiasaan, motivasi, kebutuhan, penyesuaian diri, emosional), dan faktor kematangan. Faktor eksternal siswa, yaitu faktor sosial (lingkungan keluarga, sekolah, masyarakat, dan kelompok), faktor budaya (adat istiadat, iptek, kesenian), faktor lingkungan fisik (fasilitas sekolah, fasilitas belajar, iklim) dan faktor spiritual.

Diduga bahwa faktor yang mengakibatkan rendahnya hasil belajar siswa adalah ketidakcocokkan strategi atau model pembelajaran yang digunakan pada proses pembelajaran dengan karakteristik mata pelajaran Mekanika Teknik dan Elemen Mesin (bersifat pemecahan 
masalah). Sehingga mengakibatkan siswa pasif dalam proses pembelajaran dan tidak termotivasi dalam mencari informasi sendiri (eksplorasi). Strategi pembelajaran ekspositori merupakan bentuk dari pendekatan pembelajaran yang berorientasi kepada guru. Dilakukan dengan cara menyampaikan materi pelajaran yang sudah jadi secara verbal dengan gaya komunikasi satu arah. Sehingga pengetahuan yang dimiliki siswa terbatas pada apa yang diberikan guru dan sulit mengembangkan kemampuan siswa dalam hal kemampuan sosialisasi, hubungan interpersonal, serta berpikir kritis (Depdiknas, 2008). Strategi pembelajaran ekspositori dapat digunakan dalam mengajarkan berbagai materi pelajaran, kecuali yang sifatnya pemecahan masalah (Riyanto, 2012).

Dugaan tersebut cukup rasional karena mata pelajaran Mekanika Teknik dan Elemen Mesin pada umumnya memuat materi yang bersifat pemecahan masalah, termasuk pada pembelajaran gaya. Siswa akan kesulitan memahami materi pelajaran apabila hanya mendengarkan penjelasan dari guru, siswa harus bisa mencari informasi tambahan, baik dari buku, internet, atau melalui diskusi kelompok. Disamping itu, siswa akan kesulitan meningkatkan kemampuan menyelesaikan masalah apabila hanya menyelesaikan soal yang diberikan oleh guru, siswa harus bisa membuat soal sendiri dan menyelesaikannya sebagai bentuk latihan, baik secara individu maupun kelompok.

Upaya mengatasi permasalahan tersebut adalah dengan memilih model pembelajaran yang sesuai dengan tujuan pembelajaran/pendidikan, peranan guru dan siswa, karakteristik mata pelajaran/bidang studi, dan lingkungan belajar. Model pembelajaran yang sesuai dengan pertimbangan-pertimbangan tersebut adalah Model Pembelajaran Problem Posing (pengajuan soal). Model ini memfasilitasi siswa untuk mencari informasi tambahan dan membuat soal sendiri dan menyelesaikannya sebagai bentuk latihan. Sehingga diharapkan model pembelajaran Problem Posing dapat meningkatkan hasil belajar siswa (Guvercin and Verbovskiy, 2014). Pengajuan soal dapat meningkatkan kemampuan belajar karena dengan membuat soal. Siswa perlu membaca informasi yang diberikan dan mengkomunikasikan pertanyaan secara verbal maupun tertulis. Menulis pertanyaan dari infromasi yang ada dapat menyebabkan ingatan siswa jauh lebih baik. Disamping itu, siswa diberikan kesempatan menyelidiki dan menganalisis informasi untuk dijadikan soal, kegiatan menyelidiki menentukan apa yang dipelajari. Kemampuan menerapkan penerapan dan perilaku selama kegiatan belajar. Hal tersebut menunjukan kegiatan pengajuan soal dapat memantapkan kemampuan belajar siswa (Thobroni \& Mustofa, 2013). 


\section{METODE PENELITIAN}

Metode penelitian yang digunakan yaitu Penelitian Tindakan Kelas (PTK). Penelitian ini untuk memperbaiki kualitas proses pembelajaran, meningkatkan hasil belajar, dan menemukan model pembelajaran inovatif untuk memecahkan masalah yang dialami oleh pendidik dan peserta didik. Desain PTK yang digunakan dalam penelitian ini adalah model Kemmis \& McTaggart yang terdiri dari perencanaan tindakan, pelaksanaan tindakan dan pengamatan, serta refleksi. Penelitian yang dilaksanakan terdiri dari tiga siklus.

Penelitian ini melibatkan 35 orang partisipan yang terdiri dari subjek penelitian, pengamat pelaksanaan pembelajaran, dan validator instrumen. Subjek dalam penelitian ini adalah siswa kelas X TM 3 SMK Negeri 2 Bandung yang terdiri dari 32 orang siswa. Dasar pertimbangan pemilihannya adalah bahwa kelas X TM 3 merupakan kelas yang memiliki nilai terendah dibandingkan dengan kelas lainnya. Pengamat pelaksanaan pembelajaran terdiri dari 2 orang pengamat, yakni guru dan mahasiswa. Adapun dasar pertimbangan pemilihannya adalah pengamat mengetahui proses pembelajaran menggunakan model pembelajaran Problem Posing. Validator instrumen terdiri dari 3 orang validator, yakni 1 orang dosen dan 2 orang guru. Adapun dasar pertimbangan pemilihannya adalah karena dipandang memiliki keahlian yang ada hubungannya dengan instrumen penelitian.

Instrumen pada penelitian ini adalah lembar observasi pelaksanaan pembelajaran untuk memperoleh data perencanaan dan kinerja guru dalam proses pembelajaran, dan lembar tes bentuk pilihan ganda untuk mengetahui hasil belajar siswa. Pengujian validitas lembar observasi pelaksanaan pembelajaran dan lembar tes dilakukan melalui expert judgement, serta pengujian reliabilitas, daya pembeda, dan tingkat kesukaran untuk lembar tes. Lembar tes diberikan pada kegiatan pretest dan posttest tiap siklus. Penilaian pelaksanaan pembelajaran diberikan oleh pengamat bersamaan dengan proses pembelajaran. Hasil pengambilan data akan dibandingkan setiap siklusnya, sehingga dapat dilihat peningkatannya. Hasil belajar diketahui melalui penskoran hasil pretest dan posttest tiap siklus yang kemudian dinormalisasikan dengan $\mathrm{N}$-Gain. Kriteria keberhasilan penelitian yaitu apabila hasil belajar siswa secara klasikal minimal $75 \%$ dari jumlah siswa yang mencapai KKM yang ditetapkan (70).

\section{HASIL PENELITIAN}

Hasil observasi pelaksanaan pembelajaran pada siklus I menunjukan bahwa guru melaksanakan proses pembelajaran sesuai dengan yang tercantum pada RPP, tetapi 
mahasiswa yang menjadi pengamat menilai bahwa guru tidak melaksanakan satu kegiatan pendahuluan (memberikan motivasi belajar kepada siswa) dan satu kegiatan inti (memilih soal yang diajukan berdasarkan bobot soal).

Hasil belajar siswa pada siklus I masih rendah. Skor tertinggi pada kegiatan pretest yaitu sebesar 12 dan skor terendah sebesar 5 dengan rata-rata skor 7,50. Skor tertinggi pada kegiatan posttest yaitu sebesar 12 dan skor terendah sebesar 5 dengan rata-rata skor 9,63. Rata-rata $N$-Gain sebesar 0,274 dengan interpretasi rendah. Persentase siswa yang mencapai KKM sebesar 31,3\% belum memenuhi kriteria keberhasilan pembelajaran yang ditetapkan. $(75 \%)$. Berdasarkan refleksi, kekurangan-kekurangannya antara lain; siswa belum terbiasa dengan kondisi belajar menggunakan model pembelajaran Problem Posing. Siswa belum bisa memanfaatkan waktu dengan baik, sebagian siswa masih ada yang tidak membawa modul pembelajaran, guru tidak memberikan motivasi belajar kepada siswa, dan sebagian siswa tidak turut serta dalam menyelesaikan tugas kelompok, maka perlu adanya perbaikan pada siklus II.

Hasil observasi pelaksanaan pembelajaran pada siklus II menunjukan bahwa guru melaksanakan proses pembelajaran sesuai dengan yang tercantum pada RPP. Hasil belajar siswa pada siklus II masih rendah meskipun terjadi peningkatan dari siklus I. Skor tertinggi pada kegiatan pretest yaitu sebesar 11 dan skor terendah sebesar 2 dengan rata-rata skor 8,16. Skor tertinggi pada kegiatan posttest yaitu sebesar 13 dan skor terendah sebesar 7 dengan rata-rata skor 10,75. Rata-rata $N$-Gain sebesar 0,357 dengan interpretasi sedang. Persentase siswa yang mencapai KKM sebesar 68,8\% belum memenuhi kriteria keberhasilan pembelajaran yang ditetapkan (75\%). Berdasarkan refleksi, kekurangannya antara lain: siswa masih belum bisa memanfaatkan waktu dengan baik dan sebagian siswa masih ada yang tidak turut serta dalam menyelesaikan tugas kelompok, maka perlu adanya perbaikan pada siklus III.

Hasil observasi pelaksanaan pembelajaran pada siklus III menunjukan bahwa guru melaksanakan proses pembelajaran sesuai dengan yang tercantum pada RPP. Hasil belajar siswa pada siklus III sudah sesuai dengan yang diharapkan. Skor tertinggi pada kegiatan pretest yaitu sebesar 12 dan skor terendah sebesar 4 dengan rata-rata skor 8,47. Skor tertinggi pada kegiatan posttest yaitu sebesar 13 dan skor terendah sebesar 7 dengan rata-rata skor 11,41. Rata-rata $N$-Gain sebesar 0,451 dengan interpretasi sedang. Persentase siswa yang mencapai KKM sebesar 78,1\% sudah memenuhi kriteria keberhasilan pembelajaran yang ditetapkan (75\%). Secara umum, kekurangan yang ada dalam proses pembelajaran siklus II 
sudah dapat diatasi dengan baik, walaupun masih ada hal yang masih perlu diperbaiki, yaitu manajemen waktu yang belum efektif dan efisien.

\section{PEMBAHASAN}

Hasil penelitian siklus I menunjukan bahwa hasil belajar siswa masih rendah. Hasil tersebut banyak dipengaruhi oleh beberapa hal, salah satunya proses adaptasi siswa terhadap penggunaan model pembelajaran Problem Posing. Pada proses pembelajaran siklus I terlihat bahwa siswa belum terbiasa dengan kondisi belajar yang menggunakan model pembelajaran Problem Posing. Saat anak belajar di sekolah, faktor guru dan cara mengajarnya merupakan faktor penting (Thobroni \& Mustofa, 2013). Sikap dan kepribadian guru, tinggi rendahnya pengetahuan yang dimiliki guru, dan bagaimana guru mengajarkan pengetahuan tersebut kepada peserta didiknya turut menentukan hasil belajar yang akan dicapai. Oleh karena itu, siswa harus bisa menyesuaikan diri dengan berbagai kondisi belajar agar siswa bisa mendapat hasil yang optimal dari proses belajar. Penyesuaian diri merupakan suatu proses yang dapat mengubah tingkah laku manusia.

Berdasarkan hasil observasi pelaksanaan pembelajaran siklus I, guru tidak melaksanakan satu kegiatan yang termuat pada RPP, yaitu memberikan motivasi. Hal tersebut menjadi salah satu faktor yang menyebabkan rendahnya hasil belajar siswa pada siklus I, karena pemberian motivasi belajar merupakan kegiatan yang sangat berpengaruh terhadap kesadaran, semangat, dan kesiapan siswa untuk belajar. Motif merupakan pendorong bagi suatu organism untuk melakukan sesuatu. Seseorang tidak akan mau berusaha mempelajari sesuatu dengan sebaik-baiknya jika ia tidak mengetahui pentingnya dan faedahnya dari hasil yang akan dicapai dari belajar. Motif merupakan tenaga penggerak yang memengaruhi kesiapan untuk memulai melakukan rangkaian kegiatan dalam suatu perilaku.

Pada proses pembelajaran siklus I ada sebagian siswa yang tidak membawa modul pembelajaran, hal tersebut menandakan bahwa siswa tersebut tidak siap untuk belajar. Kesiapan belajar sangat penting dalam proses pembelajaran, karena jika siswa siap untuk belajar dengan mempersiapkan berbagai hal yang diperlukan, maka proses belajar pun akan lebih optimal dan hasil belajar akan lebih baik. Kesiapan adalah keseluruhan kondisi seseorang yang membuatnya siap untuk memberi respon/jawaban di dalam cara tertentu terhadap suatu situasi (Slameto, 2010).

Proses pembelajaran menggunakan model pembelajaran Problem Posing akan membuat siswa sangat aktif ketika kegiatan mengajukan soal berlangsung. Seorang guru 
harus mampu mengendalikan kelas dengan cara memantau siswa secara merata agar keadaan kelas bisa dikendalikan dan tidak memerlukan waktu lebih banyak. Pengendalian kelas memberikan pengaruh yang sangat vital untuk mempertahankan fokus siswa terhadap tugastugasnya dan menunjukan perilaku yang baik di kelas. Guru yang efektif mengkomunikasikan sesuatu yang disebut withiness, mereka tahu apa yang dilakukan sepanjang waktu di kelas (Ormrod, 2008). Guru-guru ini selalu memantau kelas dan sering melakukan kontak mata dengan siswa secara individual. Mereka tahu kenakalan apa yang terjadi ketika kenakalan tersebut terjadi, dan mereka tahu siapa pelakunya. Ketika guru menunjukan withiness semacam itu, para siswa cenderung tetap fokus pada tugasnya dan menunjukan perilaku yang baik di kelas.

Hasil penelitian siklus II menunjukan bahwa hasil belajar siswa masih rendah mesikpun terjadi peningkatan dari siklus I. Dengan memerhatikan refleksi siklus I, dilakukan perbaikan proses pembelajaran, terutama pada pemberian motivasi belajar siswa, kesiapan siswa, dan pengendalian kelas ternyata ada peningkatan hasil belajar siswa dari siklus I.

Meski demikian, hasil belajar siswa pada siklus II masih belum mencapai target yang ditetapkan, hal tersebut dipengaruhi oleh pengendalian kelas yang belum optimal. Sebagian siswa dalam kelompoknya masih ada yang tidak turut serta dalam menyelesaikan tugas kelompok. Guru kurang merata dalam membimbing siswa untuk menyelesaikan tugas kelompok dalam proses pembelajaran, sehingga siswa tidak terkendalikan dan cenderung keluar dari fokus belajar. Di kelas, mereka seharusnya menemukan stimulasi mereka dalam tugas-tugas dan aktivitas yang berkesinambungan. Jika mereka memiliki banyak waktu luang, maka mereka akan menghasilkan stimulasi mereka sendiri, terkadang dalam bentuk perilaku yang tidak sesuai.

Pada proses pembelajaran menggunakan model pembelajaran Problem Posing, seorang guru hendaknya membagi siswa ke dalam beberapa kelompok. Hal tersebut dapat membantu siswa mendapatkan informasi lebih banyak melalui pertukaran ide antar siswa pada suatu kelompok. Pengajuan masalah melalui kelompok dapat membantu siswa dalam memikirkan ide secara lebih jauh antara sesama anggota di dalam kelompok. Dengan demikian, pengajuan masalah secara kelompok dapat menggali pengetahuan, alasan, serta pandangan antara satu siswa dan siswa yang lain (Rosli, Capraro, \& Capraro, 2014).

Hasil penelitian siklus III menunjukan bahwa hasil belajar siswa sudah sesuai dengan yang diharapkan. Pada siklus III terjadi peningkatan hasil belajar siswa dari siklus I dan siklus II. Dengan memerhatikan refleksi siklus II, dilakukan perbaikan proses pembelajaran, 
terutama pada pengendalian kelas ternyata ada peningkatan hasil dari siklus II. Meskipun demikian, ada hal yang menjadi fokus utama, yaitu manajemen waktu yang belum efektif dan efisien (Tampubolon, 2014). Kelemahan model pembelajaran Problem Posing salah satunya adalah memerlukan waktu yang cukup banyak. Seorang guru dituntut untuk bisa mempergunakan waktu dengan sebaik-baiknya. Manajemen waktu adalah memanfaatkan waktu yang dimiliki untuk melakukan hal-hal yang dianggap penting yang telah tercatat dalam tabel kerja (Akram, 2010). Sebelum menggunakan model pembelajaran Problem Posing, guru hendaknya membuat perencanaan pembelajaran dengan menyesuaikan alokasi waktu yang tersedia agar proses pembelajaran dapat berlangsung secara efektif. Disamping itu, guru hendaknya memberikan bahan ajar (materi) kepada siswa pada pertemuan sebelumnya. Hal ini dilakukan agar pada pertemuan tersebut guru bisa memulai kegiatan pengajuan soal tanpa mempertimbangkan waktu yang habis karena menjelaskan materi pelajaran.

\section{KESIMPULAN}

Hasil penelitian menunjukan adanya peningkatan hasil belajar siswa pada tiap siklus. Rata-rata $N$-Gain pada siklus I sebesar 0,274 meningkat menjadi 0,357 pada siklus II, dan menjadi 0,451 pada siklus III. Persentase siswa yang mencapai KKM pada siklus I sebesar $31,3 \%$ meningkat menjadi $68,8 \%$ pada siklus II, dan menjadi $78,1 \%$ pada siklus III. Maka dapat disimpulkan bahwa penggunaan model pembelajaran Problem Posing dapat meningkatkan hasil belajar siswa pada pembelajaran gaya dalam mata pelajaran Mekanika Teknik dan Elemen Mesin.

\section{DAFTAR PUSTAKA}

Akram, M. (2010). Time habit kebiasaan efektif mengelola waktu. Yogyakarta: Pustaka Marwa.

Guvercin, S. \& Verbovskiy, V. (2014). The effect of problem posing tasks used in mathematics instruction to mathematics academic achievement and attitudes toward mathematics. Journal: International Online Journal of Primary Education, 3 (2), hlm. $59-65$.

Menteri Pendidikan Nasional. (2008). Strategi pembelajaran dan pemilihannya. Jakarta: Mendiknas.

Ormrod, J. E. (2009). Psikologi pendidikan: Membantu siswa tumbuh dan berkembang. Terjemahan Amitya Kumara. Jakarta: Penerbit Erlangga. 
Riyanto, H. (2012). Paradigma baru pembelajaran: Sebagai referensi bagi guru/pendidik dalam implementasi pembelajaran yang efektif dan berkualitas. Jakarta: Kencana.

Rosli, R., Capraro, M., \& Capraro, R. (2014). The effects of problem posing on student mathematical learning: A meta-analysis. Journal International Education Studies, 7 (13), hlm. 227-241.

Ruhimat, T. (2013). Kurikulum dan pembelajaran oleh tim pengembangan MKDP kurikulum dan pembelajaran. Jakarta: Rajawali Pers.

Slameto. (2010). Belajar dan faktor-faktor yang memengaruhinya. Jakarta: Rineka Cipta.

Tampubolon, S. (2014). Penelitian tindakan kelas sebagai pengembangan profesi pendidik dan keilmuan. Jakarta: Penerbit Erlangga.

Thobroni, M. \& Mustofa, A. (2013). Belajar dan pembelajaran: Pengembangan wacana dan praktik pembelajaran dalam pembangunan nasional. Yogyakarta: Ar-ruzz Media. 